\title{
Rett syndrome: think outside the (skull) box
}

\author{
Emilie Borloz (D) ${ }^{1} \quad$ Laurent Villard (iD ${ }^{1} \quad$ Jean-Christophe Roux (iD ${ }^{1 *}$ \\ ${ }^{1}$ Aix Marseille Univ, INSERM, MMG, U1251, Faculté de médecine Timone, 13385, Marseille, France
}

\begin{abstract}
Rett syndrome (RTT) is a severe X-linked neurodevelopmental disorder characterized by neurodevelopmental regression between 6 and 18 months of life and associated with multi-system comorbidities. Caused mainly by pathogenic variants in the MECP2 (methyl CpG binding protein 2) gene, it is the second leading genetic cause of intellectual disability in girls after Down syndrome. RTT affects not only neurological function but also a wide array of non-neurological organs. RTT-related disorders involve abnormalities of the respiratory, cardiovascular, digestive, metabolic, skeletal, endocrine, muscular, and urinary systems and immune response. Here, we review the different aspects of RTT affecting the main peripheral groups of organs and sometimes occurring independently of nervous system defects.
\end{abstract}

\section{Keywords}

Rett syndrome, Mecp2, comorbidities, peripheral systems

\section{Peer Review}

The peer reviewers who approve this article are:

1. James H Eubanks, Department of Physiology, University of Toronto, Toronto, Canada; Department of Surgery, Division of Neurosurgery, University of Toronto, Toronto, Canada; Department of Pharmacology, Faculty of Medicine, University of Toronto, Toronto, Canada; Krembil Research Institute, Toronto, ON, CA

Competing interests: No competing interests were disclosed.

2. Maurizio Giustetto, Department of Neuroscience, University of Turin, Corso Raffaello 30, 10125 Turin, Italy Competing interests: No competing interests were disclosed.

3. Giuseppe Valacchi, Department of Biomedical and Specialist Surgical Sciences, University of Ferrara, Ferrara, Italy; Plants for Human Health Institute, Animal Science Dept., North Carolina State University, Kannapolis, NC, USA; Kyung Hee University, Department of Food and Nutrition, Seoul, South Korea Valeria Cordone, Department of Biomedical and Specialist Surgical Sciences, University of Ferrara, Ferrara, Italy Competing interests: No competing interests were disclosed. 
*Corresponding author: Jean-Christophe Roux (jean-christophe.roux@univ-amu.fr)

Competing interests: The authors declare that they have no competing interests.

Grant information: The authors are supported by INSERM, Aix Marseille Univ, and grants from the AFM-Téléthon, Rettsyndrome.org, and Association Française du Syndrome de Rett.

The funders had no role in study design, data collection and analysis, decision to publish, or preparation of the manuscript.

Copyright: $@ 2021$ Roux JC et al. This is an open access article distributed under the terms of the Creative Commons Attribution License, which permits unrestricted use, distribution, and reproduction in any medium, provided the original work is properly cited.

How to cite this article: Borloz E, Villard L and Roux JC. Rett syndrome: think outside the (skull) box. Faculty Reviews 2021 10:(59) https://doi. org/10.12703/r/10-59

Published: 29 June 2021, Faculty Reviews 10:(59) https://doi.org/10.12703/r/10-59 


\section{Introduction}

Rett syndrome (RTT) is a severe X-linked neurological disorder that is caused primarily by loss-of-function mutations in the ubiquitously expressed $M E C P 2$ (methyl $\mathrm{CpG}$ binding protein 2) gene ${ }^{1}$. It is the second most prevalent genetic cause of intellectual disability in girls ${ }^{2}$ (incidence of 1/10,000 girls) after Down syndrome. Mutations occur de novo, preventing the possibility of prenatal screening or genetic counseling; therefore, the incidence is not expected to decline. After a period of normal development, patients with RTT undergo a regression of early neurodevelopment ${ }^{3}$. The main clinical features are severe intellectual disability, microcephaly, loss of hand skills and speech, seizures, and respiratory and motor abnormalities ${ }^{4}$.

Although neurological conditions are prominent, the disease affects not only the central nervous system (CNS) but also a wide array of non-neurological organs. RTT has a complex and multifaceted clinical appearance ${ }^{5}$. This pathology evolves throughout the life span of the patient, and multi-system comorbidities, like gastrointestinal (GI), orthopedic, endocrine, or cardiac issues, are more or less prevalent ${ }^{6}$. Liver injury, urological dysfunction, adipose tissue disorders, and inflammatory response troubles are also non-neurological disorders associated with $\mathrm{RTT}^{7}$. Although most research is focused on the role of $M E C P 2$ in the CNS, the different clinical aspects identified in Mecp2 mutant animal models and RTT patients underline the importance of MECP2 in peripheral tissues. Even if most symptoms of RTT arise from neural origin, a mouse model exclusively expressing Mecp2 in neuronal and glial cells suggests that some symptoms of RTT occur independently of nervous system defects ${ }^{8}$.

According to caregivers, many of these chronic health issues cause pain and impair the quality of life of patients with RTT . Currently, treatments are aimed at alleviating symptoms but not cure RTT $^{10,11}$ and these peripheral abnormalities should be considered when planning therapeutic strategies. Here, we review the main systems affected by MECP2 mutations, besides the CNS, in RTT patients and mouse models.

\section{Respiratory system}

The most prevalent peripheral dysfunctions in RTT are breathing abnormalities ${ }^{12}$. Nearly $100 \%$ of patients with classic RTT will develop, over their life span, breathing abnormalities that can be categorized into one of two groups: hyperventilation and breath-holding ${ }^{13}$. Up to a quarter of sudden RTT-associated deaths could be caused by respiratory arrhythmia ${ }^{14}$. Both male and female Mecp2-deficient mouse models (hemizygous or heterozygous Mecp2-knockout (KO) mice) display breathing disturbances with apneas, beginning around 1 month of life and worsening over time, together with an exacerbated response to hypoxia ${ }^{15-18}$. Post-mortem analysis of Mecp2-null mice lungs showed macroscopic and histological abnormalities with the presence of infiltrating cells in different tissues of the lungs, indicating inflammation ${ }^{19}$.
The cause of these breathing irregularities has been investigated in RTT mouse models, principally in the brain stem, which has a critical role in regulating respiratory function. A conditional Mecp2-KO in the brain stem and spinal cord caused abnormal patterns of breathing ${ }^{20}$. Many neuronal mechanisms are likely to play a role in the RTT breathing phenotype $^{21}$ as imbalances in synaptic transmission ${ }^{22}$ and alteration in different neuromodulatory systems such as bioaminergic neurotransmission ${ }^{15,18}$.

A peripheral contribution to the respiratory symptoms has nevertheless been examined. Although Mecp2 is expressed in the lungs, its conditional deletion in peripheral tissues is not sufficient to perturb breathing activity. Unlike in the Mecp2-null mice, in conditional peripheral Mecp2-KO mice no gross structural abnormalities or inflammation were found in lung tissue biopsies $^{8}$. However, the presence of Mecp2 is essential for pulmonary fibrosis ${ }^{23}$. Together, these results confirm that respiratory dysfunction is linked to disruption of autonomic or brain stem function.

\section{Digestive system}

GI and nutritional troubles are frequently reported in patients with $\mathrm{RTT}^{24}$. In a cohort of 983 females with RTT, $81 \%$ had feeding problems (principally chewing difficulty, prolonged feeding time, and choking), 92\% had GI problems (gastroesophageal reflux, constipation, straining with bowel movements, and passage of hard stools), and $47 \%$ had nutritional problems (poor weight principally) ${ }^{24}$. A small percentage $(4.4 \%)$ of patients also have biliary tract disease, which may have a fatal outcome ${ }^{25}$.

Only a few studies have investigated GI dysfunction in mouse models and, although there is a well-known underweight in Mecp2-KO mice ${ }^{26}$, GI dysmotility was described only in $2016^{27}$. That study found a large increase in transit time in Mecp2-KO mice compared with controls ${ }^{27}$. Wahba et al. also showed that MECP2 was expressed in the GI tract, specifically in the enteric nervous system (ENS) in humans and mice as early as embryonic day $11.5(\mathrm{E} 11.5)^{28}$. GI motility is controlled by the myenteric plexus, part of the ENS which uses more than 30 neurotransmitters ${ }^{29}$. However, peristalsis is activated mainly by acetylcholine and inhibited by vasoactive intestinal peptide ${ }^{29}$ and nitric oxide ${ }^{30}$. Levels of nNOS (the enzyme catalyzing the production of nitric oxide) were elevated in Mecp2-KO GI tissue ${ }^{27}$. This upregulation could be, in part, responsible for GI hypomotility.

At the histological scale, Mecp2-null mice displayed a shorter colon with severe changes in its epithelium similar to those observed in colitis and abnormal localization of key membrane proteins $^{31}$. However, conditional deletion of Mecp 2 from intestinal tissue using the villin promoter, an actin binding protein expressed mainly in the microvilli of the epithelium of the gut, does not reproduce the Mecp2-null GI phenotype ${ }^{31}$. Since the conditional Mecp2-KO in non-neuronal cells does not 
display any body-weight decrease compared with the control group $^{8}$, these symptoms may have a neural origin. A central or enteric origin cannot be ruled out here since a brain- or ENS-specific Mecp2-KO does not exist. The commonly called CNS conditional KO mice were generated with the nestin-Cre transgene ${ }^{26,32}$. However, nestin is also expressed in the gut, and nestin-expressing intestinal cells give rise to enteric neurons and glia $^{33}$. A study by Deguchi et al. suggests that constipation in RTT is related to autonomic nervous system dysfunction originating in the brain stem and not in the bowe $l^{34}$. Indeed, an immunoreactivity assay showed no differences in the expression of substance P, tyrosine hydroxylase, and vasoactive intestinal peptide in girls with RTT compared with healthy controls in the gut. This is in contrast to the brain stem, where differences were found ${ }^{34}$. However, GI motility is not controlled by these neurotransmitters only, and transit perturbations could be partly caused by ENS dysfunction.

Prompted by recent evidence that bacterial and fungal gut microbiota have a role in human health and GI functions, studies have been conducted in patients with RTT $^{35-37}$. Measures of fecal calprotectin and erythrocyte sedimentation rate showed an increase linked to intestinal sub-inflammatory status in patients with RTT $^{36}$. Interestingly, patients with RTT display an altered microbiota, in terms of abundances and richness, and modified short-chain fatty acid profiles ${ }^{36}$ and these alternations were not correlated with constipation status. The study by Borghi et al. (2017) was in agreement with the latest findings; however, the authors showed that microbiota dysbiosis was related to total disease severity ${ }^{35}$. A focus on the gut mycobiota revealed a distinct genotypic profile of Candida parapsilosis in girls with RTT compared with controls, increasing its potential virulent features and the capacity to be more resistant to antifungals ${ }^{37}$. Even though mechanisms are not clearly understood yet, altered gut microbiota could be implicated in the GI pathophysiology of RTT. To resolve this question, intestinal microbiota was investigated in a female rat model of $\mathrm{RTT}^{38}$, and different abundance of microbial taxa between wild-type (WT) and RTT rat has been identified. The use of animal models allows experimental control of the diet and the host, and manipulation of the microbiota is necessary to further investigate the role of the gut microbiome in the severity and progression of RTT.

\section{Metabolism}

The liver plays a central role in all of the body's metabolic functions, such as carbohydrate, fat, or protein metabolism ${ }^{39}$. Interestingly, RTT is associated with metabolic dysfunctions and liver disease $\mathrm{e}^{40}$.

Kyle et al. (2016) investigated whether the loss of Mecp2 could cause perturbations of metabolism in a male mouse model of $\mathrm{RTT}^{41}$. Mecp 2 deletion induces severe dyslipidemia, fatty liver disease, metabolic syndrome, and insulin resistance and alters energy homeostasis. Liver-specific deletion of Mecp2 increases lipogenic enzyme transcription, leading to fatty liver disease without affecting insulin sensitivity ${ }^{41}$.
Except for the brain, which has to synthesize its own cholesterol (since this compound cannot cross the blood-brain barrier), the body's primary producer of cholesterol is the liver ${ }^{42}$. Although brain cholesterol synthesis is commonly disrupted in Mecp2-null mice, elevated cholesterol level in the liver is observed only in $129 . \mathrm{Mecp}^{\mathrm{tm} 1.1 \mathrm{Bird}}$ mice $^{43}$, and peripheral metabolic phenotype differs across genetic backgrounds ${ }^{44}$. Consistently, lipid metabolism is altered in a subset of patients with $\mathrm{RTT}^{45}$. The imbalance in plasma lipid profile is restricted to cholesterol metabolism with augmented levels of total cholesterol, low-density lipoprotein (LDL) and high-density lipoprotein (HDL) cholesterol in patients with RTT ${ }^{46}$.

The understanding of metabolic aspects and liver injuries linked to RTT reveals potential therapeutic targets but unfortunately faces limitations for therapeutic strategies such as gene therapy. Indeed, hepatotoxicity due to high off-target liver delivery of an AAV9-Mecp2 has been demonstrated in a female mouse model of RTT $^{47}$.

\section{Skeletal system}

Orthopedic comorbidities have been reported in over $80 \%$ of patients with RTT, and the most encountered disorder is scoliosis $^{48}$. Scoliosis is related to a lack of walking but is unrelated to the loss of hand skills or hand stereotypes ${ }^{48}$. These results extend our understanding of interactions between scoliosis and overall clinical severity. Surgical correction of scoliosis is mostly successful but has a very high rate of complications with a prolonged hospital stay ${ }^{49}$. Other orthopedic symptoms include hip displacement and a high prevalence of fractures ${ }^{50-52}$, which can be diminished with intravenous bisphosphonates treatment ${ }^{53}$. Several markers, such as osteocalcin or bone-specific alkaline phosphatase, which are linked to bone formation and resorption, were decreased in patients with RTT $^{54}$. These results suggest a low bone turnover that could explain altered bone mass. Altogether, these observations support the need for clinical and radiological surveillance in all patients with RTT.

Studies in a murine model of RTT confirmed low bone mass as a component of this syndrome with cortical thickness, mineralization of the medullary cavity in long bones, and low bone density in the spine ${ }^{55}$. Curvature of the spine is also present with kyphosis in the form of a $\mathrm{C}^{56}$. Interestingly, Kamal et al. (2015) showed that the skeletal phenotype caused by Mecp 2 deficiency is potentially reversible by the delayed restoration of Mecp 2 in adult mice ${ }^{57}$. These results highlight the importance of the development of gene-based therapies, especially in light of recent advances in gene therapy for bone regeneration ${ }^{58}$.

\section{Endocrine system}

The endocrine system is controlled by glands, located either in the brain (such as the pituitary and the pineal gland) or in the periphery (such as the thyroid, adrenals, or gonads). Other tissues, like the adipose tissue, which secretes leptin, a hormone inhibiting hunger and upregulated in RTT, can also contribute 
to the endocrine system ${ }^{59}$. Endocrine disorders have an impact on growth, menstrual cycles, and bones.

Hyperactivity of the hypothalamic-pituitary-adrenal (HPA) axis has been observed in animal models of $\mathrm{RTT}^{60}$, and the investigation of HPA axis function among patients with RTT shows that diurnal decline of cortisol is less steep in patients with the most severe symptoms such as frequent hyperventilation ${ }^{61}$. These preliminary results support the hypothesis that RTT is associated with aberrant HPA axis function.

In patients with RTT, the most common (59\% of patients) endocrine issue is low bone mineral content ${ }^{52}$, which is correlated with the occurrence of fractures. This alteration of bone mineral deposition may be caused by vitamin $\mathrm{D}$ deficiency ${ }^{62}$. Blue et al. (2015) showed that, compared with WT mice, female heterozygous and male Mecp2-null mice also displayed decreased mineral apposition rate, mineralizing surface, and bone formation rate/bone surface ${ }^{63}$.

Girls with RTT also frequently present alterations in the time of appearance of secondary sexual characteristics such as early pubertal onset and delayed menarche ${ }^{64}$, yet the mechanisms by which $M E C P 2$ mutations could impact pubertal pathways remain unclear.

Also, at the gland level, thyroid function has been studied in RTT and no consensus was reached ${ }^{65-67}$. A subtle decrease of levels of $\mathrm{T}_{4}$, one of the thyroid hormones, was reported in a cohort of 17 patients by Cooke et al., but no evidence of clinical hypothyroidism was found ${ }^{67}$. The study of a larger cohort of 45 girls with typical and atypical RTT showed opposite results with increased $T_{4}$ levels ${ }^{65}$. The thyroid hormones $T_{3}$ and $\mathrm{T}_{4}$ are essential for proper development; they function as transcription factors and the genes they regulate are important for brain development ${ }^{68}$. The relationship between thyroid disorders and RTT phenotype merits further investigations, especially since it is known that the lack of thyroid hormones results in intellectual deficiency ${ }^{68}$ and weight variation ${ }^{69}$.

\section{Cardiovascular system}

Cardiac abnormalities have been investigated as a cause of sudden death of unknown origin in RTT. The patients have electrocardiogram and rhythm defects, including prolonged QT interval $(\mathrm{QTc})^{70,71}$, one of the most studied cardiac risk factors for sudden death. No clinical morphological or functional changes have been demonstrated using cardiac imaging studies, although a subclinical mild decrease in systolic and diastolic ventricular function was found in a cohort of 72 girls with typical $\mathrm{RTT}^{72}$. These findings must be considered in the context of patients exhibiting autonomic dysfunctions with sympathetic over-activity, parasympathetic under-activity, and sympathovagal imbalance ${ }^{73}$.

Cardiac arrhythmias have also been reported in animal models of RTT; and these arrhythmias could be predisposed by prolonged $\mathrm{QTc}^{74}$ but also by the abnormal differentiation of cardiac progenitors, the dysregulation of cardiac genes, or cardiomyocyte structural alterations ${ }^{75}$. Baseline heart rate and blood pressure are at WT levels in Mecp 2 heterozygous females ${ }^{76}$, suggesting no defects of autonomic cardiovascular control. However, Herrera et al. (2016) showed that conditional removal of Mecp2 in cholinergic neurons was sufficient to recapitulate cardiac rhythm defects in RTT mice 77 . These results showed that Mecp2 deficiency altered autonomic cardiac control mainly via the cholinergic nervous system.

\section{Muscular system}

Muscular troubles are present at different time points of the pathology. Mild hypotonia is frequently observed before the onset of symptoms in patients with $\mathrm{RTT}^{78}$. During the late motor deterioration phase, abnormal muscle tone is observed ${ }^{79}$. Skeletal muscles in Mecp2 mutant mice were not extensively investigated except by Conti et al. $(2015)^{80}$. Mecp2 deficiency induces severe skeletal muscle atrophy with no dystrophic features other than a reduced muscle mass ${ }^{80}$. Muscle atrophy can have different causes, including necrosis (which is not observed here), abnormal innervation, or dysfunction of the neuromuscular plaque. However, the morphology of neuromuscular plaques is normal in the absence of $\mathrm{Mecp}^{80}$ and innervation is functional ${ }^{81}$. Another cause of atrophy could be the affected regeneration after muscular injuries observed in Mecp2-null mice ${ }^{80}$.

To understand whether muscular defects are cell- or non-cell-autonomous, Conti et al. generated a conditional KO for Mecp2 using the MyoD promoter, expressed in myoblasts and muscle fibers. These animals displayed normal muscle structure and myofibers and did not show any of the RTT-linked myopathy ${ }^{80}$. According to these results, Mecp2 is not required for the development and growth of skeletal muscles and these defects may be due to non-cell-autonomous mechanisms related to trophic factors ${ }^{80}$.

Skeletal muscles are rich in mitochondria, the primary organelle producing energy in the cell. Muscle biopsies of patients with RTT showed not only morphological ultrastructural abnormalities in mitochondrial number and size but also distention, vacuolation, dumb-bell shape, and membranous changes $^{82-86}$. Therefore, the muscular phenotype of RTT could also be caused, in part, by mitochondria dysfunction.

\section{Urinary system}

Urological dysfunction is infrequent but is described in a subset of patients, about $8 \%$ of a large cohort of 905 girls with typical $\mathrm{RTT}^{87}$, which is a higher incidence rate compared with the general population. The most frequent complications are urinary tract infection, kidney stones, or urine retention ${ }^{87}$ but also urinary acidification ${ }^{88}$. These symptoms are significantly correlated with the total clinical severity score. However, incontinence is not part of the RTT phenotype ${ }^{89}$.

In both male and female Mecp2-mutant mice, urological function was studied in the absence of Mecp $2^{87}$. Patterns of 
micturition were assessed, and abnormalities were found with a decreased volume of urine per spot for both sexes; no difference was found between hemizygous males and heterozygous Mecp2-KO females. As micturition troubles can lead to urine reflux from the bladder to the kidney and cause damage, kidney function was also investigated. Serum chemistry exhibited evidence of kidney failure and necropsy identified distended bladders, obstruction of the urinary tract, and moderate hydronephrosis ${ }^{87}$; this clinical observation could be a cause of mortality in these mice.

The cause of urological dysfunction in RTT is not well known yet. Nevertheless, it is noteworthy that urological problems are found in other neurological disorders like Parkinson's disease or Huntington's chorea. Urological complications could be the consequence of a dysfunction of the autonomic nervous system.

\section{Immune response}

A subclinical chronic inflammatory status has been shown in RTT patients with an increased erythrocyte sedimentation rate $^{90}$. A major cytokine upregulation was also found and was correlated with clinical severity and the inflammatory status $^{91}$. These observations suggest that immune response dysfunctions contribute to the pathophysiology of $\mathrm{RTT}^{92}$ : on one hand, with the alteration of microglia activity in the CNS that affects neural development ${ }^{93}$ and, on the other hand, with the alteration of peripheral immune cells such as macrophages. Even if several reports suggest the presence of an autoimmune component in RTT, such as oxidative damage, cytokine dysregulation, or acute-phase protein response, no "classical autoimmunity" has been shown yet ${ }^{94}$.

Mecp2 was found to be expressed in cells implicated in the immune response, such as peripheral macrophages and monocytes $^{95}$. In Mecp2-null mice, macrophage populations, including microglia, are decreased ${ }^{96}$. However, conditional KO of Mecp 2 in the macrophage was not able to generate an RTT phenotype, but the inflammatory status has not been reported yet ${ }^{97}$.

Immune response participates in RTT pathophysiology, and the genetic rescue of several macrophage and monocyte populations results in the attenuation of a subset of phenotypes and the increase of the life $\operatorname{span}^{95}$.

\section{Conclusions}

RTT is a complex disorder that impacts primarily the CNS but also several systems inducing multiple comorbidities (Figure 1). Most of these peripheral symptoms, such as breathing abnormalities or cardiac defects, are still due to Mecp2 deficiency in the brain or peripheral nervous system. However, some organs are likely affected by the lack of Mecp2 in the tissue itself. It is noteworthy that some comorbidities are also found

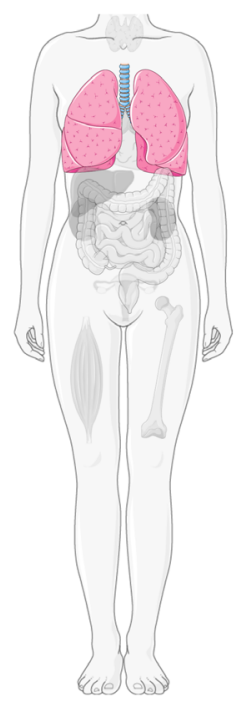

Respiratory system Breathing arrhythmias Breath-holding

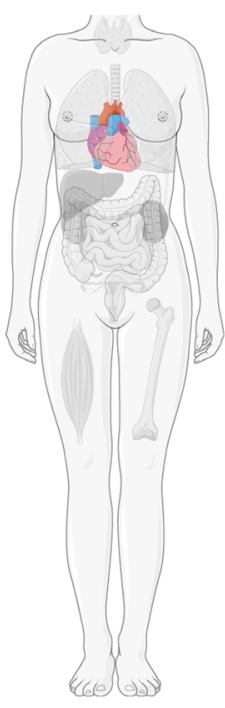

Cardiovascular system Rythm defects Prolonged QT interval No morphologic change

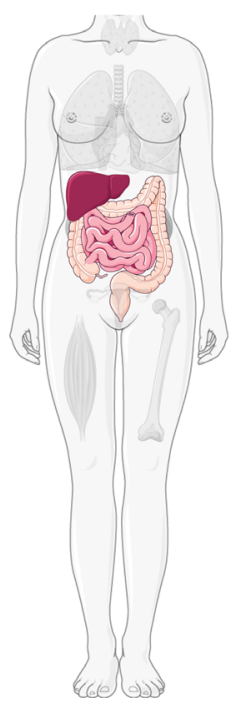

Digestive/metabolic system Gastrointestinal dysmotility Altered microbiota Liver disease

Metabolism dysfunction
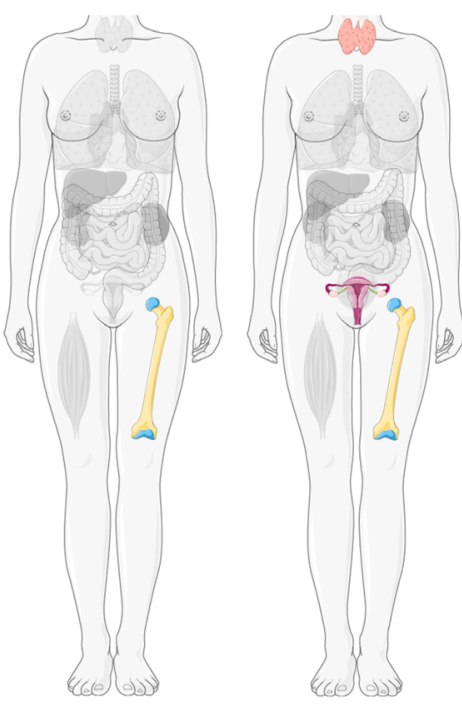

Endocrine system

Skeletal system Scoliosis Fractures Low bone mineral content Delayed menarche Thyroid hormones

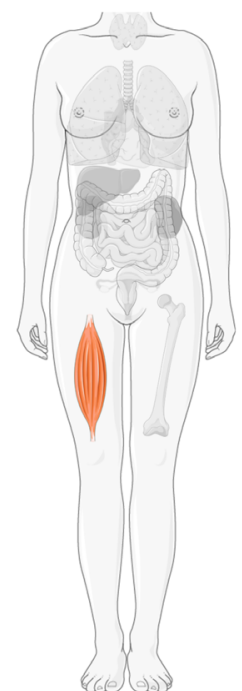

Muscular system Mild hypotonia Muscle atrophy

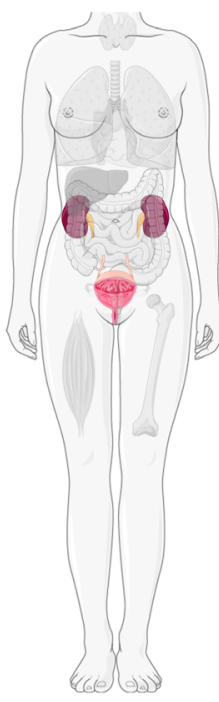

Urinary system

Urinary tract infection Kidney stones Urine retention

Figure 1. Rett syndrome-related organ system disorders involve abnormalities of the respiratory, cardiovascular, digestive, metabolic, skeletal, endocrine, muscular, and urinary system. Graphical representation of the organ systems affected in a patient with Rett syndrome. The schematic art pieces used in this figure were provided by Servier Medical Art (https://smart.servier.com/). Servier Medical Art by Servier is licensed under the terms of Creative Commons Attribution 3.0 Unported License (CC BY 3.0). 
in other diseases affecting multiple organs and are certainly consequences of other symptoms. Therefore, these clinical manifestations may not be specific to RTT.

The various studies on mouse models have shown that they reproduce certain comorbidities fairly accurately. However, these models, generally Mecp2-KO males, are genetically quite distant from the mutations found in female patients, complicating the translation of studies and therapeutic trials in patients.

In order to improve disease management and the patients' quality of life, multi-disciplinary medical follow-up is key. Indeed, these "peripheral" symptoms cause significant pain and may be responsible for sudden death. The complexity of the disease is a hindrance to research, mainly for therapy, and the multi-organ damage is an additional challenge. A better understanding of this multi-system disorder, thanks to model systems and human studies, will provide better care for patients and hopefully advance therapeutic development.

\section{Acknowledgments}

We thank Florence Molinari and Lucile Brun (Aix Marseille University, INSERM, MMG, U1251, Faculté de médecine Timone, Marseille, France) and Yann Ehinger (Department of Neurology, University of California, San Francisco, USA) for helpful discussions.
1. Amir RE, van den Veyver IB, Wan M, et al.: Rett syndrome is caused by mutations in X-linked MECP2, encoding methyl-CpG-binding protein 2. Nat Genet 1999; 23(2): 185-8. PubMed Abstract | Publisher Full Text

2. Neul JL, Kaufmann WE, Glaze DG, et al.: Rett syndrome: Revised diagnostic criteria and nomenclature. Ann Neurol. 2010; 68(6): 944-50. PubMed Abstract | Publisher Full Text | Free Full Text

3. Hagberg B, Aicardi J, Dias K, et al.: A progressive syndrome of autism, dementia, ataxia, and loss of purposeful hand use in girls: Rett's syndrome: report of 35 cases. Ann Neurol. 1983; 14(4): 471-9. PubMed Abstract | Publisher Full Text

4. Chahrour M, Zoghbi HY: The story of Rett syndrome: From clinic to neurobiology. Neuron. 2007; 56(3): 422-37.

PubMed Abstract | Publisher Full Text

5. Gold WA, Krishnarajy R, Ellaway C, et al.: Rett Syndrome: A Genetic Update and Clinical Review Focusing on Comorbidities. ACS Chem Neurosci. 2018; 9(2): $167-76$.

PubMed Abstract | Publisher Full Text

6. - Fu C, Armstrong D, Marsh E, et al:: Multisystem comorbidities in classic Rett syndrome: A scoping review. BMJ Paediatr Open. 2020; 4(1): e000731. PubMed Abstract | Publisher Full Text | Free Full Text | Faculty Opinions Recommendation

7. Wang J, Xiao Y, Liu C, et al.: Emerging physiological and pathological roles of MeCP2 in non-neurological systems. Arch Biochem Biophys. 2021; 700 108768.

PubMed Abstract | Publisher Full Text | Faculty Opinions Recommendation

8. Ross PD, Guy J, Selfridge J, et al.: Exclusive expression of MeCP2 in the nervous system distinguishes between brain and peripheral Rett syndrome-like phenotypes. Hum Mol Genet. 2016; 25(20): 4389-404. PubMed Abstract | Publisher Full Text | Free Full Text

9. Symons FJ, Byiers B, Tervo RC, et al:: Parent-reported pain in Rett syndrome. Clin J Pain. 2013; 29(8): 744-6.

PubMed Abstract | Publisher Full Text | Free Full Tex

10. Katz DM, Berger-Sweeney JE, Eubanks JH, et al.: Preclinical research in Rett syndrome: Setting the foundation for translational success. Dis Model Mech. 2012; 5(6): 733-45.

PubMed Abstract | Publisher Full Text | Free Full Text

11. Lombardi LM, Baker SA, Zoghbi HY: MECP2 disorders: From the clinic to mice and back. J Clin Invest. 2015; 125(8): 2914-23.

PubMed Abstract | Publisher Full Text | Free Full Text

12. Kerr AM: A review of the respiratory disorder in the Rett syndrome. Brain Dev. 1992; 14 Suppl: S43-5. PubMed Abstract

13. Tarquinio DC, Hou W, Neul JL, et al:: The course of awake breathing disturbances across the lifespan in Rett syndrome. Brain Dev. 2018; 40(7): 515-29.

PubMed Abstract | Publisher Full Text | Free Full Text | Faculty Opinions Recommendation

14. Kerr AM, Armstrong DD, Prescott RJ, et al.: Rett syndrome: Analysis of deaths in the British survey. Eur Child Adolesc Psychiatry. 1997; 6 Suppl 1: 71-4. PubMed Abstract

15. Viemari JC, Roux JC, Tryba AK, et al:: Mecp2 deficiency disrupts norepinephrine and respiratory systems in mice. J Neurosci. 2005; 25(50): 11521-30. PubMed Abstract | Publisher Full Text | Free Full Text

16. Johnson $\mathrm{CM}$, Cui $\mathrm{N}$, Zhong $\mathrm{W}$, et al.: Breathing abnormalities in a female mouse model of Rett syndrome. J Physiol Sci. 2015; 65(5): 451-9. PubMed Abstract | Publisher Full Text | Free Full Text

17. W Ward CS, Huang TW, Herrera JA, et al:: Loss of MeCP2 Function Across Several Neuronal Populations Impairs Breathing Response to Acute Hypoxia. Front Neurol. 2020; 11: 593554

PubMed Abstract | Publisher Full Text | Free Full Text

Faculty Opinions Recommendation

18. Roux JC, Dura E, Villard L: Tyrosine hydroxylase deficit in the chemoafferent and the sympathoadrenergic pathways of the Mecp2 deficient mouse. Neurosci Lett. 2008; 447(1): 82-6.

PubMed Abstract | Publisher Full Text

19. Kida H, Takahashi T, Nakamura Y, et al.: Pathogenesis of Lethal Aspiration Pneumonia in Mecp2-null Mouse Model for Rett Syndrome. Sci Rep. 2017; 7(1): 12032.

PubMed Abstract | Publisher Full Text | Free Full Text

20. Ward CS, Arvide EM, Huang TW, et al.: MeCP2 is critical within HoxB1-derived tissues of mice for normal lifespan. J Neurosci. 2011; 31(28): 10359-70. PubMed Abstract | Publisher Full Text | Free Full Text

21. Ramirez JM, Ward CS, Neul JL: Breathing challenges in Rett syndrome: Lessons learned from humans and animal models. Respir Physiol Neurobiol. 2013; 189(2): 280-7

PubMed Abstract | Publisher Full Text | Free Full Text

22. Zoghbi HY: Postnatal neurodevelopmental disorders: Meeting at the synapse? Science. 2003; 302(5646): 826-30.

PubMed Abstract | Publisher Full Tex

23. Hu B, Gharaee-Kermani M, Wu Z, et al.: Essential role of MeCP2 in the regulation of myofibroblast differentiation during pulmonary fibrosis. $\mathrm{Am}$ Pathol. 2011; 178(4): 1500-8.

PubMed Abstract | Publisher Full Text | Free Full Text

24. Motil KJ, Caeg E, Barrish JO, et al.: Gastrointestinal and nutritional problems occur frequently throughout life in girls and women with Rett syndrome.

J Pediatr Gastroenterol Nutr. 2012; 55(3): 292-8.

PubMed Abstract | Publisher Full Text | Free Full Text

25. Motil KJ, Lane JB, Barrish JO, et al.: Biliary Tract Disease in Girls and Young Women With Rett Syndrome. J Pediatr Gastroenterol Nutr. 2019; 68(6): 799-805. PubMed Abstract | Publisher Full Text | Free Full Text |

Faculty Opinions Recommendation

26. Guy J, Hendrich B, Holmes M, et al:: A mouse Mecp2-null mutation causes neurological symptoms that mimic Rett syndrome. Nat Genet. 2001; 27(3): 322-6.

PubMed Abstract | Publisher Full Text

27. Wahba G, Schock SC, Cudd S, et al: Activity and MeCP2-dependent regulation of nNOS levels in enteric neurons. Neurogastroenterol Motil. 2016; 28(11): 1723-30

PubMed Abstract | Publisher Full Text

28. Wahba G, Schock SC, Claridge E, et al:: MeCP2 in the enteric nervous system. Neurogastroenterol Motil. 2015; 27(8): 1156-61. PubMed Abstract | Publisher Full Text

29. Spencer NJ, Hu H: Enteric nervous system: Sensory transduction, neural 
circuits and gastrointestinal motility. Nat Rev Gastroenterol Hepatol. 2020; 17(6): 338-51.

PubMed Abstract | Publisher Full Text | Free Full Text |

Faculty Opinions Recommendation

30. Bódi N, Szalai Z, Bagyánszki M: Nitrergic Enteric Neurons in Health and Disease-Focus on Animal Models. Int J Mol Sci. 2019; 20(8): 2003. PubMed Abstract | Publisher Full Text | Free Full Text

31. Millar-Büchner P, Philp AR, Gutierrez N, et al:: Severe changes in colon epithelium in the Mecp2-null mouse model of Rett syndrome. Mol Cell Pediatr. 2016; 3(1): 37.

PubMed Abstract | Publisher Full Text | Free Full Text

32. Chen RZ, Akbarian S, Tudor M, et al.: Deficiency of methyl-CpG binding protein2 in CNS neurons results in a Rett-like phenotype in mice. Nat Genet. 2001; 27(3): 327-31.

PubMed Abstract | Publisher Full Text

33. Belkind-Gerson J, Carreon-Rodriguez A, Benedict LA, et al:: Nestin-expressing cells in the gut give rise to enteric neurons and glial cells. Neurogastroenterol Motil. 2013; 25(1): 61-9.e7.

PubMed Abstract | Publisher Full Text | Free Full Text

34. Deguchi K, Reyes C, Chakraborty S, et al:: Substance $\mathbf{P}$ immunoreactivity in the enteric nervous system in Rett syndrome. Brain Dev. 2001; 23 Suppl 1: S127-S132.

PubMed Abstract | Publisher Full Text

35. Borghi E, Borgo F, Severgnini M, et al:: Rett Syndrome: A Focus on Gut Microbiota. Int J Mol Sci. 2017; 18(2): 344

PubMed Abstract | Publisher Full Text | Free Full Text

36. Strati F, Cavalieri D, Albanese D, et al.: Altered gut microbiota in Rett syndrome. Microbiome. 2016; 4(1): 41.

PubMed Abstract | Publisher Full Text | Free Full Text

37. Strati F, Calabrò A, Donati C, et al.: Intestinal Candida parapsilosis isolates from Rett syndrome subjects bear potential virulent traits and capacity to persist within the host. BMC Gastroenterol. 2018; 18(1): 57 PubMed Abstract | Publisher Full Text | Free Full Text | Faculty Opinions Recommendation

38. Gallucci A, Patterson KC, Weit AR, et al:: Microbial community changes in a female rat model of Rett syndrome. Prog Neuropsychopharmacol Biol Psychiatry. 2021; 109: 110259 .

PubMed Abstract | Publisher Full Text | Faculty Opinions Recommendation

39. Mitra V, Metcalf J: Metabolic functions of the liver. Anaesthesia \& Intensive Care Medicine. 2012; 13: 54-5.

Publisher Full Text

40. Kyle SM, Vashi N, Justice MJ: Rett syndrome: A neurological disorder with metabolic components. Open Biol. 2018; 8(2): 170216. PubMed Abstract | Publisher Full Text | Free Full Text

41. Kyle SM, Saha PK, Brown HM, et al:: MeCP2 co-ordinates liver lipid metabolism with the NCoR1/HDAC3 corepressor complex. Hum Mol Genet. 2016; 25(14): 3029-3041.

PubMed Abstract | Publisher Full Text | Free Full Text

42. Zlokovic BV: The blood-brain barrier in health and chronic neurodegenerative disorders. Neuron. 2008; 57(2): 178-201. PubMed Abstract | Publisher Full Text

43. Buchovecky CM, Turley SD, Brown HM, et al:: A suppressor screen in Mecp2 mutant mice implicates cholesterol metabolism in Rett syndrome. Nat Genet. 2013; 45(9): 1013-20

PubMed Abstract | Publisher Full Text | Free Full Text |

Faculty Opinions Recommendation

44. Cobolli Gigli C, Scaramuzza L, Gandaglia A, et al:: MeCP2 Related Studies Benefit from the Use of CD1 as Genetic Background. PLoS One. 2016; 11(4) e0153473.

PubMed Abstract | Publisher Full Text | Free Full Text

45. Segatto M, Trapani L, Di Tunno I, et al.: Cholesterol metabolism is altered in Rett syndrome: A study on plasma and primary cultured fibroblasts derived from patients. PLoS One. 2014; 9(8): e104834.

PubMed Abstract | Publisher Full Text | Free Full Text

46. Sticozzi C, Belmonte G, Pecorelli A, et al.: Scavenger receptor B1 posttranslational modifications in Rett syndrome. FEBS Lett. 2013; 587(14): 2199-204.

PubMed Abstract | Publisher Full Text

47. Matagne V, Borloz E, Ehinger $\mathrm{Y}$, et al:: Severe offtarget effects following intravenous delivery of AAV9-MECP2 in a female mouse model of Rett syndrome. Neurobiol Dis. 2021; 149: 105235.

PubMed Abstract | Publisher Full Text

48. Percy AK, Lee HS, Neul JL, et al:: Profiling scoliosis in Rett syndrome. Pediatr Res. 2010; 67(4): 435-9.

PubMed Abstract | Publisher Full Text | Free Full Text

49. Hammett T, Harris A, Boreham B, et al.: Surgical correction of scoliosis in Rett syndrome: Cord monitoring and complications. Eur Spine J. 2014; 23 Suppl 1(Suppl 1): S72-5.

PubMed Abstract | Publisher Full Text | Free Full Text

50. Tay G, Graham H, Graham HK, et al.: Hip displacement and scoliosis in Rett syndrome - screening is required. Dev Med Child Neurol. 2010; 52(1): 93-8. PubMed Abstract | Publisher Full Text

51. Jefferson AL, Woodhead HJ, Fyfe S, et al.: Bone mineral content and density in Rett syndrome and their contributing factors. Pediatr Res. 2011; 69(4): 293-8. PubMed Abstract | Publisher Full Text | Free Full Text

52. Motil KJ, Ellis KJ, Barrish JO, et al.: Bone mineral content and bone mineral density are lower in older than in younger females with Rett syndrome. Pediatr Res. 2008; 64(4): 435-9.

PubMed Abstract | Publisher Full Text | Free Full Text

53. Lambert AS, Rothenbuhler A, Charles $P$, et al:: Lower incidence of fracture after IV bisphosphonates in girls with Rett syndrome and severe bone fragility. PLoS One. 2017; 12(10): e0186941.

PubMed Abstract | Publisher Full Text | Free Full Text

54. Roende G, Petersen J, Ravn K, et al.: Low bone turnover phenotype in Rett syndrome: Results of biochemical bone marker analysis. Pediatr Res. 2014; 75(4): 551-8. PubMed Abstract | Publisher Full Text

55. Shapiro JR, Bibat G, Hiremath G, et al:: Bone mass in Rett syndrome: Association with clinical parameters and MECP2 mutations. Pediatr Res. 2010; 68(5): 446-51.

PubMed Abstract | Publisher Full Text | Free Full Text

56. O'Connor RD, Zayzafoon M, Farach-Carson MC, et al:: Mecp2 deficiency decreases bone formation and reduces bone volume in a rodent model of Rett syndrome. Bone. 2009; 45(2): 346-56.

PubMed Abstract | Publisher Full Text | Free Full Text

57. Kamal B, Russell D, Payne A, et al.: Biomechanical properties of bone in a mouse model of Rett syndrome. Bone. 2015; 71: 106-14. PubMed Abstract | Publisher Full Text | Free Full Text

58. Shapiro G, Lieber R, Gazit D, et al:: Recent Advances and Future of Gene Therapy for Bone Regeneration. Curr Osteoporos Rep. 2018; 16(4): 504-11. PubMed Abstract | Publisher Full Text

59. Blardi $\mathrm{P}$, de Lalla A, D'Ambrogio $\mathrm{T}$, et al.: Rett syndrome and plasma leptin levels. J Pediatr. 2007; 150(1): 37-9.

PubMed Abstract | Publisher Full Tex

60. McGill BE, Bundle SF, Yaylaoglu MB, et al:: Enhanced anxiety and stressinduced corticosterone release are associated with increased $\mathrm{Crh}$ expression in a mouse model of Rett syndrome. Proc Natl Acad Sci U S A. 2006; 103(48): in a mouse $18267-72$. 18267-72.
PubMed Abstract | Publisher Full Text | Free Full Text

61. C Byiers BJ, Payen A, Feyma T, et al:: Associations Among Diurnal Salivary Cortisol Patterns, Medication Use, and Behavioral Phenotype Features in a Community Sample of Rett Syndrome. Am J Intellect Dev Disabil. 2020; 125(5): 353-368.

PubMed Abstract | Publisher Full Text | Faculty Opinions Recommendation

62. Motil KJ, Barrish JO, Lane $\mathrm{J}$, et al:: Vitamin $\mathrm{D}$ deficiency is prevalent in girls and women with Rett syndrome. J Pediatr Gastroenterol Nutr. 2011; 53(5): 569-74. PubMed Abstract | Publisher Full Text | Free Full Text

63. Blue ME, Boskey AL, Doty SB, et al:: Osteoblast function and bone histomorphometry in a murine model of Rett syndrome. Bone. 2015; 76: 23-30. PubMed Abstract | Publisher Full Text | Free Full Text

64. Killian JT, Lane JB, Cutter GR, et al.: Pubertal development in Rett syndrome deviates from typical females. Pediatr Neurol. 2014; 51(6): 769-75. PubMed Abstract | Publisher Full Text | Free Full Text

65. Stagi S, Cavalli L, Congiu L, et al:: Thyroid function in Rett syndrome. Horm Res Paediatr. 2015; 83(2): 118-25. PubMed Abstract | Publisher Full Text

66. Huppke P, Roth C, Christen HJ, et al.: Endocrinological study on growth retardation in Rett syndrome. Acta Paediatr. 2001; 90(11): 1257-61. PubMed Abstract | Publisher Full Text

67. Cooke DW, Naidu S, Plotnick L, et al.: Abnormalities of thyroid function and glucose control in subjects with Rett syndrome. Horm Res. 1995; 43(6): 273-8. PubMed Abstract | Publisher Full Text

68. Thompson CC, Potter GB: Thyroid hormone action in neural development. Cereb Cortex. 2000; 10(10): 939-45. PubMed Abstract | Publisher Full Text

69. Fox CS, Pencina MJ, D'Agostino RB, et al:: Relations of thyroid function to body weight: Cross-sectional and longitudinal observations in a community-based sample. Arch Intern Med. 2008; 168(6): 587-92. PubMed Abstract | Publisher Full Text | Faculty Opinions Recommendation

70. Crosson J, Srivastava S, Bibat GM, et al.: Evaluation of QTc in Rett syndrome: Correlation with age, severity, and genotype. Am J Med Genet A. 2017; 173(6): 1495-501.

PubMed Abstract | Publisher Full Text | Free Full Text

71. Ellaway CJ, Sholler G, Leonard H, et al.: Prolonged QT interval in Rett syndrome. Arch Dis Child. 1999; 80(5): 470-2.

PubMed Abstract | Publisher Full Text | Free Full Text

72. Co Felice $\mathrm{C}$, Maffei S, Signorini $\mathrm{C}$, et al.: Subclinical myocardial dysfunction in Rett syndrome. Eur Heart J Cardiovasc Imaging. 2012; 13(4): 339-45. PubMed Abstract | Publisher Full Text | Faculty Opinions Recommendation

73. Kumar A, Jaryal A, Gulati S, et al.: Cardiovascular Autonomic Dysfunction in 
Children and Adolescents With Rett Syndrome. Pediatr Neurol. 2017; 70: 61-6. PubMed Abstract | Publisher Full Text

74. McCauley MD, Wang T, Mike E, et al.: Pathogenesis of lethal cardiac arrhythmias in Mecp2 mutant mice: Implication for therapy in Rett syndrome. Sci Transl Med. 2011; 3(113): 113ra125.

PubMed Abstract | Publisher Full Text | Free Full Text

75. Hara M, Takahashi T, Mitsumasu C, et al.: Disturbance of cardiac gene expression and cardiomyocyte structure predisposes Mecp2-null mice to arrhythmias. Sci Rep. 2015; 5: 11204

PubMed Abstract | Publisher Full Text | Free Full Text

76. Bissonnette JM, Knopp SJ, Maylie J, et al:: Autonomic cardiovascular control in methyl-CpG-binding protein 2 (Mecp2) deficient mice. Auton Neurosci. 2007 136(1-2): 82-9.

PubMed Abstract | Publisher Full Text | Free Full Text

77. Herrera JA, Ward CS, Wehrens XHT, et al:: Methyl-CpG binding-protein 2 function in cholinergic neurons mediates cardiac arrhythmogenesis. Hum Mol Genet. 2016; 25(22): 4983-95

PubMed Abstract | Publisher Full Text | Free Full Tex

78. Heilstedt HA, Shahbazian MD, Lee B: Infantile hypotonia as a presentation of Rett syndrome. Am J Med Genet. 2002; 111(3): 238-42. PubMed Abstract | Publisher Full Text

79. Killian JT, Lane JB, Lee HS, et al.: Scoliosis in Rett Syndrome: Progression, Comorbidities, and Predictors. Pediatr Neurol. 2017; 70: 20-5. PubMed Abstract | Publisher Full Text | Free Full Text

80. Conti V, Gandaglia A, Galli F, et al:: MeCP2 Affects Skeletal Muscle Growth and Morphology through Non Cell-Autonomous Mechanisms. PLoS One. 2015; 10(6): e0130183.

PubMed Abstract | Publisher Full Text | Free Full Text

81. Eyre JA, Kerr AM, Miller S, et al:: Neurophysiological observations on corticospinal projections to the upper limb in subjects with Rett syndrome. J Neurol Neurosurg Psychiatry. 1990; 53(10): 874-9. PubMed Abstract | Publisher Full Text | Free Full Text

82. Cardaioli E, Dotti MT, Hayek G, et al:: Studies on mitochondrial pathogenesis of Rett syndrome: Ultrastructural data from skin and muscle biopsies and mutational analysis at mtDNA nucleotides 10463 and 2835. J Submicrosc Cyto Pathol. 1999; 31(2): 301-4. PubMed Abstract

83. Wakai S, Kameda K, Ishikawa Y, et al:: Rett syndrome: Findings suggesting axonopathy and mitochondrial abnormalities. Pediatr Neurol. 1990; 6(5): 339-43.

PubMed Abstract | Publisher Full Text

84. Eeg-Olofsson O, Al-Zuhair AG, Teebi AS, et al:: Abnormal mitochondria in the Rett syndrome. Brain Dev. 1988; 10(4): 260-2. PubMed Abstract | Publisher Full Text

85. Eeg-Olofsson O, Al-Zuhair AG, Teebi AS, et al.: Rett syndrome: A mitochondrial disease? J Child Neurol. 1990; 5(3): 210-4.

PubMed Abstract | Publisher Full Text
86. Ruch A, Kurczynski TW, Velasco ME: Mitochondrial alterations in Rett syndrome. Pediatr Neurol. 1989; 5(5): 320-3.

PubMed Abstract | Publisher Full Text

87. Ward CS, Huang TW, Herrera JA, et al.: Loss of MeCP2 Causes Urological Dysfunction and Contributes to Death by Kidney Failure in Mouse Models of Rett Syndrome. PLoS One. 2016; 11(11): e0165550.

PubMed Abstract | Publisher Full Text | Free Full Text

88. Assadi F, Crowe C, Rouhi O: Hyperkalemic distal renal tubular acidosis associated with Rett syndrome. Pediatr Nephrol. 2006; 21(4): 588-90. PubMed Abstract | Publisher Full Text

89. Giesbers S, Didden R, Radstaake M, et al:: Incontinence in Individuals with Rett Syndrome: A Comparative Study. J Dev Phys Disabil. 2012; 24(3): 287-300. PubMed Abstract | Publisher Full Text | Free Full Text

90. Cortelazzo A, de Felice C, Guerranti R, et al.: Subclinical inflammatory status in Rett syndrome. Mediators Inflamm. 2014; 2014: 480980. PubMed Abstract | Publisher Full Text | Free Full Text

91. Leoncini S, de Felice C, Signorini C, et al:: Cytokine Dysregulation in MECP2and CDKL5-Related Rett Syndrome: Relationships with Aberrant Redox Homeostasis, Inflammation, and $\omega$-3 PUFAs. Oxid Med Cell Longev. 2015; 2015 421624.

PubMed Abstract | Publisher Full Text | Free Full Text

92. Pecorelli A, Cervellati C, Cordone V, et al:: Compromised immune/ inflammatory responses in Rett syndrome. Free Radic Biol Med. 2020; 152: $100-6$.

PubMed Abstract | Publisher Full Text | Faculty Opinions Recommendation

93. Paolicelli RC, Ferretti MT: Function and Dysfunction of Microglia during Brain Development: Consequences for Synapses and Neural Circuits. Front Synaptic Neurosci. 2017; 9: 9

PubMed Abstract | Publisher Full Text | Free Full Text

94. de Felice $C$, Leoncini S, Signorini $C$, et al:: Rett syndrome: An autoimmune disease? Autoimmun Rev. 2016; 15(4): 411-6. PubMed Abstract | Publisher Full Text

95. C Cronk JC, Derecki NC, Ji E, et al.: Methyl-CpG Binding Protein 2 Regulates Microglia and Macrophage Gene Expression in Response to Inflammatory Stimuli. Immunity. 2015; 42(4): 679-91. PubMed Abstract | Publisher Full Text | Free Full Text Faculty Opinions Recommendation

96. Derecki NC, Cronk JC, Lu Z, et al.: Wild-type microglia arrest pathology in a mouse model of Rett syndrome. Nature. 2012; 484(7392): 105-9. PubMed Abstract | Publisher Full Text | Free Full Text | Faculty Opinions Recommendation

97. Wolf $\mathrm{Y}$, Boura-Halfon S, Cortese N, et al:: Brown-adipose-tissue macrophages control tissue innervation and homeostatic energy expenditure. Nat Immunol. 2017; 18(6): 665-74.

PubMed Abstract | Publisher Full Text | Free Full Text

Faculty Opinions Recommendation 